Vol. XXV No 2

\title{
STUDY REGARDING THE PLANNING STAGE OF THE ROMANIAN PUBLIC PROCUREMENT PROCESS
}

\author{
Ioan Gabriel POPA*, Roxana ISPAS** \\ *“Nicolae Bălcescu" Land Forces Academy, Sibiu, Romania \\ **University of Craiova, Romania
}

popaigabi@yahoo.com, roxispas1972@yahoo.com

\begin{abstract}
In order to award a public procurement contract for the acquisition of a product, work or service, the contracting authority must follow a succession of stages, which represent a public procurement process. As a stage of the public procurement process, planning represents all the activities carried out in public institutions that determine their main objectives, the manner in which they are achieved, and what resources will be used during the process. Planning the procurement process is crucial. Failure to properly implement it results in errors and problems during the process of awarding and implementing the contract. The general objective of the paper is to identify and solve the problems that arise during the process of planning the public procurement in Romania, by identifying and anticipating some directions leading to the improvement of the entire public procurement system.
\end{abstract}

Keywords: procurement, process, public, stage, needs, products, services, work

\section{Introduction}

Over the years, both public administration, public sector institutions and businesses, and private property owners, have considered the spending of "public money" a rather delicate issue, given that it requires strict adherence to certain requirements and principles, such as: non-discrimination, transparency, proportionality, equal treatment, etc.; and the decision to use the money has to be justified and defensible. This spending of state money is done by the so-called "public procurement", defined as "the procedure that a contracting authority has to undertake in accordance with the law for concluding a contract with one or more economic operators for the supply of products, provision of services or the execution of works for consideration" [1].
Law no. 98/2016 regulates the way public procurement and the entire award process are carried out, addressing issues such as: general procurement rules, economic operators, contracting entities, application areas, award procedures and the development of the whole process [2].

\section{The Concept of Public Procurement Process}

"Procurement or public procurement is, in essence, the acquisition of works, products or services by means of a public procurement contract by one or more contracting authorities from the economic operators designated by them, whether the works, products or services are intended or not to achieve a public interest" [3]. 
In order to obtain a product, work or service after the award of a public procurement contract, the contracting authority must follow a succession of stages, which represent a public procurement process. Procurement activities are logically structured, meaning that each activity included in the process adds value to the outcome of the previous activity in order to obtain reasonable assurance that the defined objectives will be achieved upon completion of the process.
Throughout the budget year, any contracting authority purchases products, services and / or works in a certain quantity and with a certain monetary value. Small or very small acquisitions are often unplanned, while for more complex types of procurement the contracting authorities plan their purchases in advance. For each of the two approaches, the contracting authorities carry out public procurement processes.

The public procurement process takes place in four successive stages:

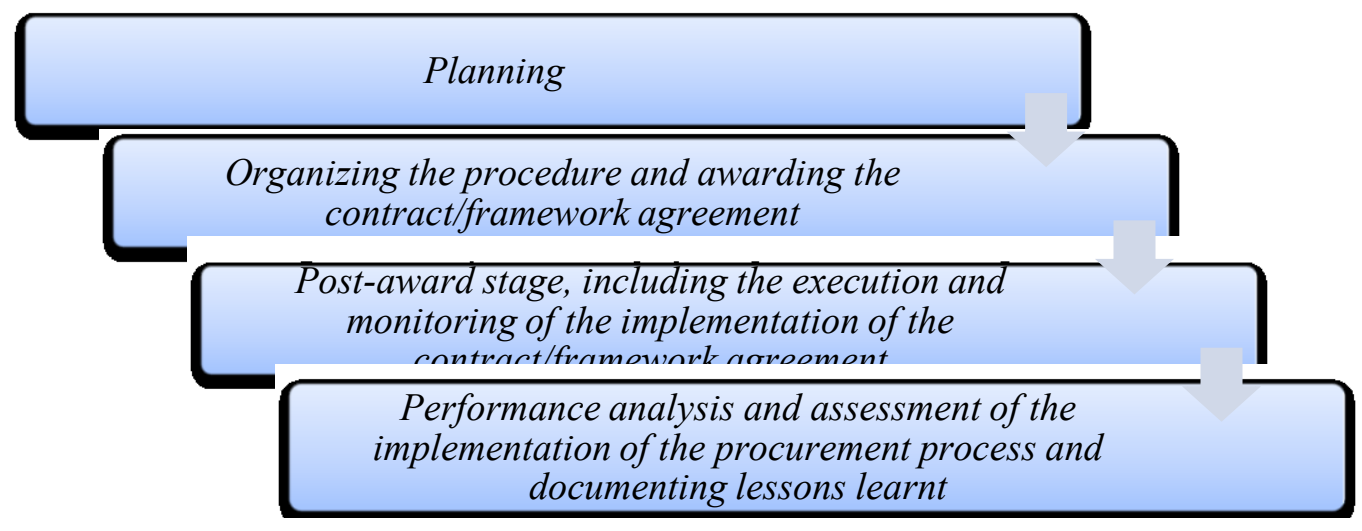

Figure 1: Stages of the public procurement process

\section{Theoretical Aspects of the Planning Stage in the Public Procurement Process}

Nowadays, all organizations consider purchases to be an essential strategic asset, which implies that strategic procurement decisions are taken at the highest level of leadership. Thus, for an efficient management of the work of contracting authorities it is recommended to plan public procurement. In any organization, managers, in one way or another, anticipate the process of public procurement in order to determine their goals and implementation modalities, as well as their resources and the manner of allocating them.

Planning within the public procurement process consists of all the work done in public institutions that determine their main goals, how they are to be achieved, and what resources will be used during the process. Within the goal-setting activity, the following questions are asked:
- What do we need?

- Why do we need it?

- When do we need it?

- How much does the product, service or work cost?

- What are the expected effects of getting them?

During the planning stage, the contracting authority must first identify its own needs, which are materialized by each of its specialized departments into necessity reports. The stage ends with the head of the contracting authority's approval of the documentation together with the contracting strategy for the procedure and together with the models of documents made available to economic operators through the Electronic Public Procurement System (SEAP) (see http: //www.demo.elicitatie.ro/pub).

The documents specific to the planning stage and the sequence of their development are presented in the figure below: 
4. Study on the Development of Specific Planning Documents

\subsection{Needs Report}

The assessment of the contracting authority's needs is necessary to initiate a procurement process and involves completing a needs report and transmitting it to the national public procurement department. The report, which includes the needs of the contracting authority, "is an ning stage documents

internal document issued by each compartment within the contracting authority in the last quarter of the current year for the next year, covering the identified needs for products, services and works and the unitary / total price of the needs" [4].

For example, the following presents a one time needs report:

Table 1 Needs report of the maintenance department

\begin{tabular}{|c|c|c|c|c|c|c|c|}
\hline No. & $\begin{array}{c}\text { Name of } \\
\text { products, } \\
\text { service/ work } \\
\text { and technical } \\
\text { characteristics }\end{array}$ & $\begin{array}{c}\text { Budgetary } \\
\text { chapter }\end{array}$ & $\begin{array}{c}\text { Budgetary } \\
\text { item }\end{array}$ & CPV & Unit & $\begin{array}{c}\text { Minimum } \\
\text { quantity }\end{array}$ & $\begin{array}{c}\text { Unitary } \\
\text { price } \\
\text { estimated } \\
\text { without } \\
\text { VAT in lei }\end{array}$ \\
\hline 1 & $\begin{array}{l}\text { Passenger } \\
\text { minibus }\end{array}$ & 65.10 .06 .01 & 20.01 .06 & $34114400-3$ & Pcs. & 1 & 168.000 \\
\hline
\end{tabular}

\subsection{Annual Procurement Strategy (S.A.A.P)}

As an explanatory document, S.A.A.P. substantiates the budgetary needs, outlines how the contracting authority identified the needs and considers the public procurement that responds to these needs for the coming year, in conjunction with the budget execution. Officially assumed by the institution, S.A.A.P. may also be a guarantee for procurement officers who will be able to present at any time arguments in the Court of Auditors in case of ex-post controls on the purpose, logic and timeliness of the acquisitions made.
P.A.A.P. is part of this S.A.A.P. and is a "management tool used to plan and monitor the procurement process portfolio at the contracting authority level to plan the resources needed to run the processes and to verify how the objectives of the local / regional / national development strategy are met, where applicable. It shall be drawn up on the basis of the needs reports sent by the contracting authorities' compartments and shall include all the public procurement / framework agreements that the contracting authority intends to assign in the course of the following year" [5]. 
Upon receipt of the approved budget, the contracting authority re-arranges its priorities according to the approved funds and updates the P.A.A.P.

Table 2 Model for the Public procurement program

\begin{tabular}{|l|c|c|c|c|c|c|c|}
\hline $\begin{array}{c}\text { Type and } \\
\text { object } \\
\text { of the contract }\end{array}$ & $\begin{array}{c}\mathrm{CPV} \\
\text { code }\end{array}$ & $\begin{array}{c}\text { Estimated } \\
\text { contract } \\
\text { value } \\
\text { without } \\
\text { VAT }\end{array}$ & $\begin{array}{c}\text { Funding } \\
\text { source }\end{array}$ & $\begin{array}{c}\text { Established } \\
\text { procedure }\end{array}$ & $\begin{array}{c}\text { Estimated } \\
\text { date for } \\
\text { the } \\
\text { commenc } \\
\text { ement of } \\
\text { the } \\
\text { procedure }\end{array}$ & $\begin{array}{c}\text { Estimated } \\
\text { date for the } \\
\text { completion } \\
\text { of the } \\
\text { procedure }\end{array}$ & $\begin{array}{c}\text { How to } \\
\text { proceed } \\
\text { online } \\
\text { / offline }\end{array}$ \\
\hline $\begin{array}{l}\text { Passenger } \\
\text { minibus }\end{array}$ & $\begin{array}{l}34114 \\
400-3\end{array}$ & 168.000 & $\begin{array}{c}\text { State } \\
\text { budget }\end{array}$ & $\begin{array}{c}\text { Open } \\
\text { auction }\end{array}$ & 10.02. & 10.04 & online \\
\hline $\begin{array}{l}\text { Maintenance } \\
\text { equipment }\end{array}$ & $\begin{array}{c}43313 \\
100-1\end{array}$ & 650.000 & $\begin{array}{c}\text { State } \\
\text { budget }\end{array}$ & $\begin{array}{c}\text { Open } \\
\text { auction }\end{array}$ & 11.03 & 11.06 & offline \\
\hline
\end{tabular}

In order to clarify the term of public procurement, it should be noted that the legislator should identify two ways of purchasing products, services or works:

a) using procurement procedures: where the contracting authority follows a set of rules stipulated by laws used to achieve a particular outcome in procurement, namely the award of a public procurement contract;

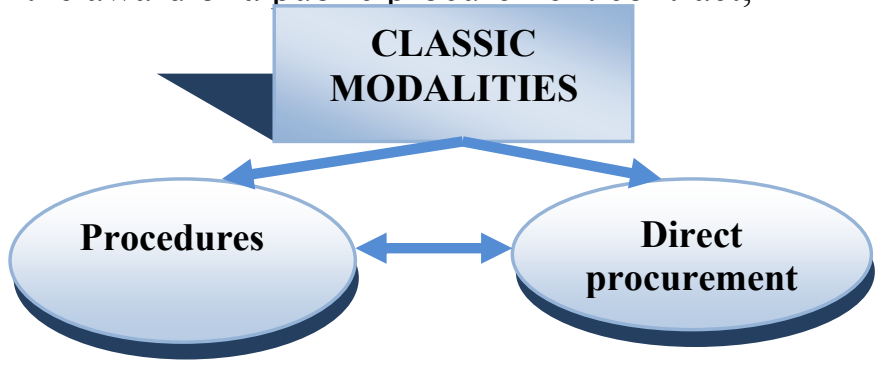

b) using award procedures: where the contracting authority applies the exceptions to the law or special cases.

Please note that the relationship between the award modality and the procedures is high to low. To this end, we present it as a scheme:

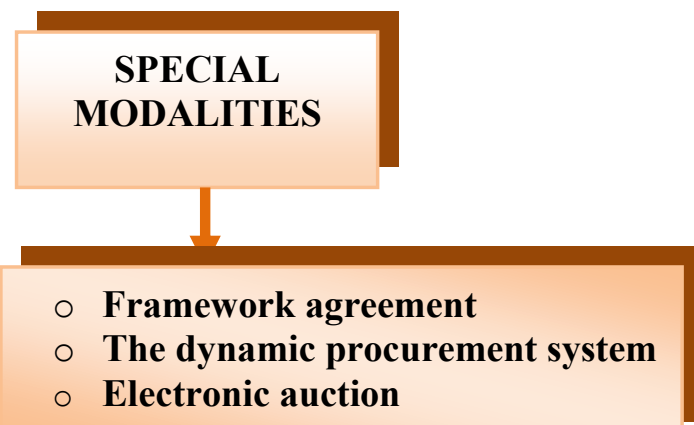

Figure 3: Award modalities

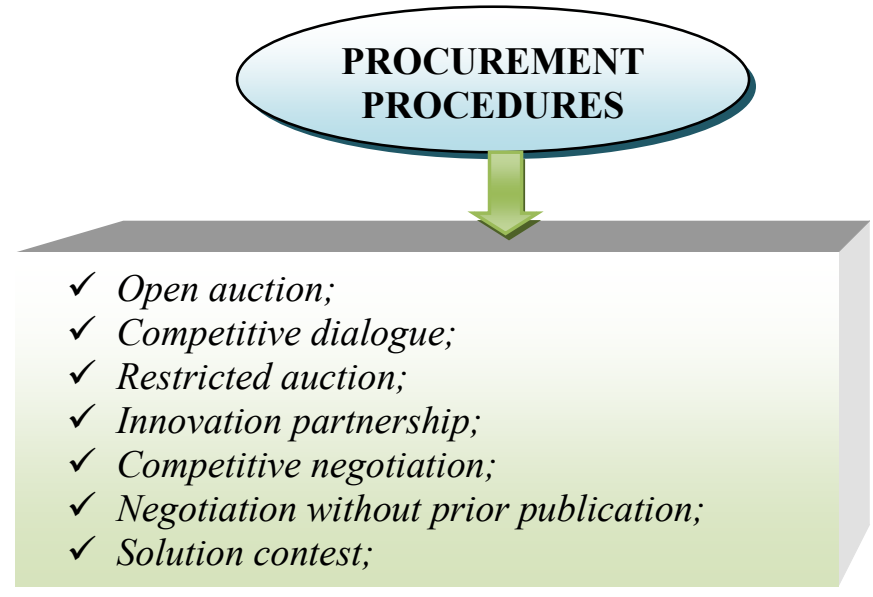

Figure 4: Procurement procedures 


\subsection{The Contracting Strategy}

The "Contracting Strategy" document reflects the type of approach to the public procurement process that the contracting authority proposes to address. Each type of procurement initiated by the contracting authority with a value of more than RON 135,060 , excluding VAT, for products or services, respectively works, if the estimated value of the acquisition, excluding VAT, is higher than 450,200 lei, will be accompanied by a Contracting strategy.

\subsection{Award Documentation}

The award documentation accompanies each of the launched public procurement process, actually being a clear and detailed description of what the contracting authority wants to purchase and the procedure by which this acquisition will be made. It is designed to ensure "full, correct and explicit information" of potential bidders about the needs of the contracting authority, the rules it has chosen for the process of award the contract / framework agreement that meets the need and the obligations that the winner will have later.

The award documentation must contain all requirements, criteria, rules and other information necessary to ensure that the tender / candidate is fully, fairly and explicitly informed of how the award procedure is applied.

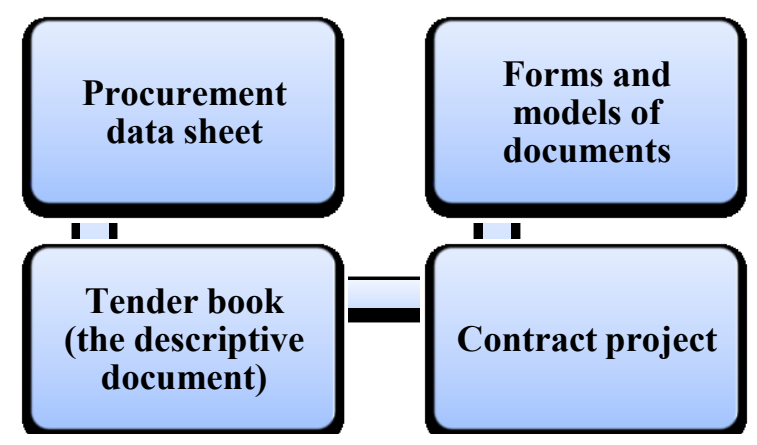

Figure 5: Award documents

A. The purchase data sheet contains:

- "standard general information, together with the formalities to be fulfilled in connection with the award procedure in question, tailored to the context under which the acquisition falls;

- issues / requirements that may be covered by the DUAE (Commission Implementing Regulation (EU) 2016/7 of 5 January 2016);

- qualification and selection criteria, if any;

- information on the participation guarantee;

- the way in which the technical and financial proposals must be drafted and structured;

- the award criterion to be applied;
- judicial remedies that can be used" [6].

B. The Single European Procurement Document (DUAE) is provided in electronic format using the standard format established by the European Commission, consisting in affidavit of the economic operator on the fulfillment of the qualification and selection criteria. DUAE was designed by the European Commission as a facilitating instrument standardizing the participation of EU firms in procedures in all Member States, as a tool to reduce the administrative burden on economic operators and reducing the burden of qualification document management and evaluation by the contracting authorities. Subsequently, only the winner of the procedure must produce the supporting 
documents and certificates that effectively prove the fulfillment of the requirements.

C. The tender book (or descriptive document) contains technical specifications that represent requirements, prescriptions, technical features that enable each product, service or work to be objectively described so as to meet the needs of the contracting authority. The description of the procurement item needs be clear, coherent and as objective as possible.

D. The contract draft refers to the obligation of the contracting authority to include in the contract specific clauses enabling the contracting authority to pursue any claim for damages that the contractor might have against the suspect third party for non-compliance with the obligations assumed by the firm commitment.

\section{Conclusion}

Planning the procurement process is crucial. Failure to properly implement it results in errors and problems in the process of awarding the contract and in implementing it.Poor and unrealistic planning produces effects such as (but not limited to):

- Generating situations that could lead to the cancellation of the procedure following the clarification questions / requests from economic operators - in the stage of preparation of the tenders, after the launch of the procedure;

- Obtaining an insufficient number of offers in order to be able to ensure real competition or to obtain low quality offers in the tender evaluation stage;

o Establishing assessment factors that, although correctly formulated, do not help to achieve the objectives of the contracting authorities - in the stage of application of the award criterion.

In public procurement, the "seeing and doing" approach does NOT work, since the contracting authority has the obligation of making purchases as it has itself proposed through the award documentation. Although it requires analysis and organization, when it is done correctly, planning the procurement process brings at least the following benefits:

O It reduces uncertainty - planning allows the identification and determination of the necessary steps in order to obtain a corresponding result;

○ It increases understanding - by "visualizing" the process and the result of the contract and by gaining a global picture that supports the decision-making process throughout the procurement process;

O It increases efficiency - by determining the resources needed and by defining how activities must be carried out;

○ It facilitates improvements and reduces the likelihood of violation of procurement legislation and diminishes the number of mistakes;

O It reduces the risk of errors occurring during the procedure and implementation of the contract.

\section{References}

[1] Şerban Dumitru-Daniel, Poziţia favorizantă a operatorilor economici la procedurile de atribuire a contractelor de achiziţie publică, Dreptul Magazine, no. 7, 2008, p.179.

[2] Dan Cimpoeru, Achiziții publice. Concesiuni. Remedii și căi de atac, C. H. Beck Publishing House, Bucharest, 2016, p.18.

[3] Article 1 of Law no. 98/2016 on public procurement.

[4] Article 3 para. (1) of H.G. 395/2016 of June 2, 2016, for the approval of the Methodological Norms for the application of the provisions regarding the award of the public procurement contract / framework agreement of Law no. 98/2016 on public procurement. 
[5] Article 12 para. (1) of H.G. 395/2016 of June 2, 2016, for the approval of the Methodological Norms for the application of the provisions regarding the award of the public procurement contract / framework agreement of Law no. 98/2016 on public procurement.

[6] Article 20 para. (1) of H.G. 395/2016 of June 2, 2016, for the approval of the Methodological Norms for the application of the provisions regarding the award of the public procurement contract / framework agreement of Law no. 98/2016 on public procurement. 